\title{
21. THE DEGREE OF HETEROGENEITY IN BASALTS NEAR THE HAYES FRACTURE ZONE, MID-ATLANTIC RIDGE: HOLES 561, 562, AND 5641
}

\author{
Joyce C. Brannon, Department of Earth and Planetary Sciences and McDonnell Center for the Space Sciences, \\ Washington University ${ }^{2}$
}

\begin{abstract}
Analyses of samples from Chemical Group II, Hole 561; Chemical Group I, Hole 562; and two pillows and a flow from Hole 564 show that the chemical groups and the individual structures are compositionally homogeneous for the data presented here except for the alkalies, $\mathrm{Na}_{2} \mathrm{O}$ and $\mathrm{Cs}$, and transition metals, $\mathrm{FeO}^{\circ}$ and $\mathrm{Co}$, and sometimes $\mathrm{Sc}$ and $\mathrm{Cr}$. The scatter in the alkalies is attributed to alteration and the scatter in the transition metals is attributed to a short-range segregation model. Although the pillows and flow from Hole 564 are each compositionally homogeneous, their compositions are distinct from one another. These results cannot support the preliminary interpretation by shipboard scientists that the basalts from Hole 564 comprise a single chemical group.
\end{abstract}

\section{INTRODUCTION}

Geologists often assume that a single sample is petrographically and chemically representative of an entire rock body, especially if there are no visible textural heterogeneities. It is also commonly assumed that such a sample is homogeneous to within the limits of analytical uncertainty. These assumptions have been accepted by generations of geologists who could easily obtain large samples from the field. With the advent of lunar science and drill core studies where sample availability, sample size, and the knowledge of field relations are restricted, it is prudent to shed these assumptions.

Quantitative petrogenetic modeling is used in an effort to describe compositional differences among related basalts and their mantle sources. One factor that affects accuracy of model predictions is the degree of heterogeneity of a basalt flow. This study was undertaken to determine the degree of compositional heterogeneity in three proposed chemical groups of Leg 82 basalts.

\section{METHODS}

Samples were obtained as either one-fourth core segments of the working half of the core or as 1-inch paleomagnetic cores that were bored from the original core, investigated, and then returned to the working half of the core. Calcite veins and fractures were avoided during sampling. The external surfaces that were in contact with the drilling equipment were ground off with silicon carbide grinding paper. The samples were placed in an ultrasonic cleaner in distilled water to remove any loose particles and then dried at $90^{\circ} \mathrm{C}$. Each sample was crushed in a Plattner steel mortar to pea-sized particles and then powdered and homogenized in an alumina canister with a Shatterbox (SPEX Industries, Inc., Metuchen, N J). The total masses of the samples range from 2.9-11.8 $\mathrm{g}$ for Hole 561, 6.2-25.0 g for Hole 562, and $11.0-26.1 \mathrm{~g}$ for Hole 564 .

Instrumental neutron activation analysis (INAA) was used to analyze 100-mg splits of the powder that had been weighed and sealed into clean ultrapure silica tubing (T21 Suprasil, Heraeus-Amersil, Sayreville, New Jersey, outside diameter $=5 \mathrm{~mm}$ ). Samples from Holes

\footnotetext{
${ }^{1}$ Bougault, H., Cande, S. C., et al., Init. Repts. DSDP, 82: Washington (U.S. Govt. Printing Office).

2 Address: Box 1169, Washington University, St. Louis, MO 63130.
}

562 and 564 were analyzed in the first experiment and samples from Hole 561 plus another split of the powdered sample from Hole 564 (564-6-4, 38-40 cm [Piece 2D]) were analyzed in a second experiment. In both experiments, samples and standards were irradiated for $20 \mathrm{hrs}$. with a thermal neutron flux of $4.0 \times 10^{13} \mathrm{~cm}^{-2} \mathrm{~s}^{-1}$ in the University of Missouri (Columbia) research reactor. Samples were each radioassayed twice, once between 6-12 days and again between 27-32 days after the irradiation. Gamma-ray spectral data were reduced with the TEABAGS programs of Lindstrom and Korotev (1982).

The following comparator standards were used. The concentration value used is listed in parentheses (same units as Table 1). USGS basalt BCR-1: $\mathrm{FeO}^{*}$ (total $\mathrm{Fe}$ as $\mathrm{FeO}, 12.1$ ), $\mathrm{Na}_{2} \mathrm{O}$ (3.27), $\mathrm{Sc}$ (31.6), $\mathrm{Co}(36.0$ ), Cs (0.94), La (24.6), Ce (53.7), Sm (6.80), Eu (1.92), Tb (1.10), Yb (3.37), $\mathrm{Lu}(0.526)$, Hf (5.2), and Th (6.0). Knippa basalt (in-house standard): $\mathrm{Cr}$ (485), Ni (360), and $\mathrm{Ta}(6.3)$. For $\mathrm{Br}$, no standard was used. Concentration values were estimated from the $554.4 \mathrm{keV}$ photopeak of ${ }^{82} \mathrm{Br}$ using the pertinent nuclear and detector efficiency parameters. Because of the uncertainties in these parameters, particularly the flux and neutron capture cross section, all $\mathrm{Br}$ concentrations may be systematically high or low, but the values are known relative to one another within each experiment.

A separate split of powdered sample from 564-6-4, 38-40 cm (Piece 2D) was analyzed in each of the two experiments. These results (Columns 1 and 2) and the difference between them (Column $\Delta$ ) along with the estimate of analytical precision (Column $\sigma$ ) are listed in Table 1 . The estimate of precision is one standard deviation $(1 \sigma)$ based on the counting statistics and other factors associated with a single analysis (Lindstrom and Korotev, 1982). Tests in this laboratory involving multiple analyses of the same sample have shown this to be a good approximation to the true sample standard deviations. The ratio $\mathrm{s} / \sigma$, where $s$ is the sample standard deviation, averages unity over all elements and ranges from $0.3-3.0$ (R. Korotev, pers. comm., 1983). Column $\Delta$ in Table 1 reflects both typical analytical precision and sample heterogeneity for the samples analyzed here. For only $\mathrm{FeO}^{*}, \mathrm{Cr}$, and Hf, does $\Delta$ exceed $\sigma$ by more than a factor of 2 . The estimate of relative analytical precision at these concentration levels for the elements listed in Table $1(100[\sigma / \bar{x}])$ is listed in the last column and is applicable to the data listed in all other tables.

The discrepancies found in $\mathrm{FeO}^{*}, \mathrm{Cr}$, and $\mathrm{Hf}$ concentrations between two splits of the same powder could be explained as (1) an underestimate of analytical precision for those elements at those concentration levels or (2) by heterogeneity within the powdered portion of the sample. Sample 1 listed in Table 1 was radioassayed twice in the same experiment. The differences between the concentrations for each element including $\mathrm{FeO}^{*}, \mathrm{Cr}$, and $\mathrm{Hf}$ are less than or equal to $\sigma$, except for $\mathrm{Co}, \mathrm{Yb}$, and $\mathrm{Hf}$, which are less than $2 \sigma$. This suggests that the discrepancies found in $\mathrm{FeO}^{*}, \mathrm{Cr}$, and $\mathrm{Hf}$ concentrations can be attributed to small-scale heterogeneity in splits from the same sample powder $\left(100[\Delta / \overline{\mathrm{x}}]=\right.$ relative heterogeneity; $2.3 \%$ for $\mathrm{FeO}^{*}, 5.5 \%$ for $\mathrm{Cr}$, and $7.1 \%$ for $\mathrm{Hf}$ ). 
Table 1. Precision of replicate analyses of Sample 564-6-4, 38-40 cm (Piece 2D).

\begin{tabular}{lcccccc}
\hline & & & & & & $\begin{array}{c}\text { A.U. } \\
(\%)\end{array}$ \\
& 1 & 2 & $\bar{x}$ & $\Delta$ & $\sigma$ & $(\%)$ \\
\hline $\mathrm{FeO}^{*}$ & 11.02 & 10.77 & 10.90 & 0.25 & 0.11 & 1.0 \\
$\mathrm{Na}_{2} \mathrm{O}$ & 2.31 & 2.31 & 2.31 & 0 & 0.03 & 1.3 \\
$\mathrm{Sc}$ & 41.9 & 41.8 & 41.85 & 0.1 & 0.4 & 1.0 \\
$\mathrm{Cr}$ & 228 & 241 & 234.5 & 13 & 3 & 1.3 \\
$\mathrm{Co}$ & 44.8 & 44.4 & 44.6 & 0.4 & 0.4 & 0.9 \\
$\mathrm{Ni}$ & 97 & 134 & 106 & 18 & 26 & 25 \\
$\mathrm{Cs}$ & 0.34 & 0.31 & 0.325 & 0.03 & 0.05 & 15 \\
$\mathrm{La}$ & 3.85 & 3.91 & 3.88 & 0.06 & 0.06 & 1.5 \\
$\mathrm{Ce}$ & 11.3 & 10.8 & 11.05 & 0.5 & 0.3 & 2.7 \\
$\mathrm{Sm}$ & 3.47 & 3.42 & 3.445 & 0.05 & 0.06 & 1.7 \\
$\mathrm{Eu}$ & 1.21 & 1.21 & 1.21 & 0 & 0.03 & 2.5 \\
$\mathrm{~Tb}$ & 0.94 & 0.98 & 0.96 & 0.04 & 0.04 & 4.2 \\
$\mathrm{Yb}$ & 3.72 & 3.69 & 3.705 & 0.03 & 0.08 & 2.2 \\
$\mathrm{Lu}$ & 0.579 & 0.58 & 0.58 & 0.001 & 0.015 & 2.6 \\
$\mathrm{Hf}$ & 2.78 & 2.59 & 2.685 & 0.19 & 0.09 & 3.4 \\
$\mathrm{Ta}$ & 0.37 & 0.41 & 0.39 & 0.04 & 0.04 & 10 \\
$\mathrm{Th}$ & 0.30 & 0.22 & 0.26 & 0.08 & 0.05 & 19 \\
\hline
\end{tabular}

Note: $1,2=$ two separate splits of 564-6-4, 38-40 cm (Piece 2D); $\overline{\mathrm{x}}=$ mean; $\Delta=$ the difference in concentrations of 1 and $2 ; \sigma$ $=$ one standard deviation uncertainty estimate of a single analysis based principally on counting statistics; A.U. $(\%)=$ $\%$ analytical uncertainty $=(\sigma / \overline{\mathrm{x}}) 100$; and $\mathrm{FeO}^{*}=$ total $\mathrm{Fe}$ as $\mathrm{FeO} . \mathrm{FeO}^{*}$ and $\mathrm{Na}_{2} \mathrm{O}$ concentrations are weight percent (wt.\%), all others are parts per million (ppm).

\section{CHEMICAL GROUPS I AND II, HOLE 561}

Only $6 \mathrm{~m}$ of basalts and basalt breccias from a $15-\mathrm{m}$ cored section of the basement at Site 561 were recovered. Three lithologic units from the basement-sediment interface to the bottom of the core were identified (aphyric basalt, basalt breccia, and aphyric pillow basalt). On the basis of shipboard XRF (X-ray fluorescence) analyses, two compositionally distinct chemical groups were identified; Chemical Group I is LREE (light rare earth element) enriched and Chemical Group II is LREE depleted relative to chondrites. Chemical Group I correlates with Lithologic Unit 1 and Chemical Group II correlates with Lithologic Units 2 and 3. Subsequent analyses of samples from this site confirm the shipboard results. Analyses for 1 sample from Chemical Group I (a split of powder from a shipboard sample) and 15 samples from Chemical Group II are listed in Table 2.

The LREE-enriched nature of basalts from Chemical Group I relative to a chondritic REE (rare earth element) distribution and the LREE-depleted nature of basalts from Chemical Group II are illustrated in Figure 1 (chondrite values from Haskin et al., 1968). Mixed occurrence of both LREE-enriched and LREE-depleted basalts at DSDP sites is uncommon. Site 561 is the second hole drilled during Leg 82 where both types of basalts were recovered. This mixed occurrence was found before at Holes 413 (Leg 49) and 504B (Legs 69-70). The significance of finding both enriched and depleted basalts at the same site is discussed by Bougault et al., Drake et al., Weaver et al., Hertogen et al., Jenner et al., Rideout and Schilling, Dupré et al., all this volume.

The basalts identified on the basis of similar composition to Chemical Group II are fine-grained vesicular aphyric pillow basalts or basalt breccias. The vesicles ( 2 $\mathrm{mm}$ in size), some of which are clay filled, are dispersed throughout the basalts and are impractical if not impossible to avoid in a sample. Both Lithologic Units 2 and 3 contain fractures and calcite veins. Minor alteration, which manifests itself as brown coloration as opposed to the gray color of the fresh portions of the rocks, occurs along these fractures. This type of alteration appears to be related to the ease of access of seawater along cracks, joints, and generally more permeable areas. Lithologic Unit 2 has undergone brecciation of the basalt, sedimentation, and consolidation of that sediment. Only fresh portions of the basalt were collected as samples.

In addition to the analyses of samples from Hole 561, Table 2 lists the mean $(\overline{\mathrm{x}})$ and sample standard deviation (s) for Chemical Group II, and one sigma ( $\sigma$ ) uncertainty estimate of a single analysis. Specimens from Samples 561-2-3, 52-54 cm (Piece 4A) and 561-3-2, 56$60 \mathrm{~cm}$ (Piece 3E) are not included in the mean or standard deviation because they contain higher $\mathrm{Br}$ concentration (by a factor of 3 ) than the average sample from Hole 561. Presumably increased $\mathrm{Br}$ concentration corresponds to increased seawater-rock interactions. For only $\mathrm{FeO}^{*}, \mathrm{Co}$, and $\mathrm{Cs}$, does s exceed $\sigma$ by more than a factor of 2 .

Hart (1976) lists the average MORB (mid-ocean ridge basalts) Cs concentration as $0.013 \mathrm{ppm}$. This low abundance element provides a sensitive indicator for alteration in the abyssal tholeiites. Very often Cs concentrations are high in samples that show no other chemical effects of alteration processes (Hart, 1969). Clays, which fill the vesicles of this basalt, display marked cation exchange properties. Usually $\mathrm{Ca}^{2+}$ and $\mathrm{Na}^{+}$are the exchangeable cations, but $\mathrm{K}^{+}, \mathrm{Cs}^{+}, \mathrm{Sr}^{2+}$, and $\mathrm{Mg}^{2+}$ are exchangeable to varying degrees (Deer et al., 1966; Hart, 1969). The range in Cs concentrations in Chemical Group II of Hole $561(0.06-0.33 \mathrm{ppm})$ yields a higher sample standard deviation than analytical uncertainty and can be attributed to addition of Cs during alteration.

$\mathrm{Br}$ and $\mathrm{Cs}$ concentrations are not well correlated in these samples. Cs concentrations probably vary directly with the amount of clay present in the sample, and $\mathrm{Br}$ concentrations are probably higher in samples that are closer to cracks and joints that seawater can permeate more easily. A plausible explanation for the lack of correlation between $\mathrm{Br}$ and $\mathrm{Cs}$ is that clay-filled vesicles are found throughout the basalts at this site, rather than just near cracks and fractures.

Two samples each were cut from two different pieces of basalt from Sections 561-2-1 and 561-2-2 (Samples 561-2-1, 71-73 cm [Piece 4D]; 561-2-1, 78-80 cm [Piece 4D]; 561-2-2, 18-21 cm [Piece 1D]; and 561-2-2, 25-28 $\mathrm{cm}$ [Piece 1D]). The specimens from 561-2-2 (Piece 1D) have essentially identical concentrations for all elements listed in Table 2 to within $1 \sigma$ analytical uncertainty. Such is not the case for the specimens from 561-2-1 (Piece $4 \mathrm{D})$. $\mathrm{Co}$, Th, and $\mathrm{FeO}^{*}$ concentrations are outside $2 \sigma$ analytical uncertainty of each other, but all other element concentrations are identical within $1 \sigma$ analytical uncertainty. These differences found in samples $5 \mathrm{~cm}$ apart on a single hand-specimen are approximately the same order of magnitude as small-scale sample heterogeneity analo- 
Table 2. Elemental abundances of basalts from Chemical Groups I and II, Hole 561.

\begin{tabular}{|c|c|c|c|c|c|c|c|c|c|c|c|c|c|c|c|c|c|c|c|}
\hline $\begin{array}{l}\text { Core-Section } \\
\text { Interval (in cm) } \\
\text { Piece }\end{array}$ & $\begin{array}{c}1-1 \\
28-31 \\
1 C\end{array}$ & $\begin{array}{c}1-1 \\
119-122 \\
9 \mathrm{~A}\end{array}$ & $\begin{array}{l}1-2 \\
3-6 \\
1 \mathrm{~A}\end{array}$ & $\begin{array}{c}1-2 \\
36-38 \\
3\end{array}$ & $\begin{array}{l}2-1 \\
6-8 \\
1 \mathrm{~B}\end{array}$ & $\begin{array}{c}2-1 \\
71-73 \\
4 \mathrm{D}\end{array}$ & $\begin{array}{c}2-1 \\
78-80 \\
4 \mathrm{D}\end{array}$ & $\begin{array}{c}2-1 \\
86-88 \\
4 E\end{array}$ & $\begin{array}{c}2-2 \\
18-21 \\
1 D\end{array}$ & $\underset{25-28}{2-2}$ & $\begin{array}{c}2-2 \\
61-63 \\
2 \mathrm{~A}\end{array}$ & $\begin{array}{c}2-2 \\
80-82 \\
3\end{array}$ & $\begin{array}{c}2-3 \\
28-30 \\
2\end{array}$ & $\begin{array}{c}2-3^{a} \\
52-54 \\
4 A\end{array}$ & $\begin{array}{c}3-1 \\
140-142 \\
9 \mathrm{~J}\end{array}$ & $\begin{array}{c}3-2^{\mathrm{a}} \\
56-60 \\
3 \mathrm{E}\end{array}$ & $\sigma$ & $\bar{x}$ & $\mathrm{~s}$ \\
\hline $\mathrm{FeO}^{\circ}$ & 9.02 & 10.15 & 9.90 & 11.21 & 10.38 & 11.06 & 10.00 & 10.72 & 10.57 & 10.45 & 10.12 & 10.65 & 10.60 & 8.91 & 10.40 & 9.01 & 0.11 & 10.48 & 0.39 \\
\hline $\mathrm{Na}_{2} \mathrm{O}$ & 2.37 & 2.40 & 2.34 & 2.45 & 2.46 & 2.39 & 2.42 & 2.39 & 2.48 & 2.48 & 2.43 & 2.34 & 2.52 & 2.55 & 2.43 & 2.34 & 0.03 & 2.42 & 0.05 \\
\hline $\mathrm{Sc}$ & 35.6 & 42.0 & 41.8 & 41.7 & 42.1 & 40.7 & 40.9 & 41.3 & 42.4 & 42.0 & 41.7 & 41.2 & 42.7 & 46.0 & 41.8 & 43.4 & 0.4 & 41.7 & 0.6 \\
\hline $\mathrm{Cr}$ & 399 & 231 & 226 & 228 & 235 & 222 & 228 & 228 & 226 & 223 & 230 & 226 & 229 & 240 & 224 & 232 & 3 & 227 & 3 \\
\hline Co & 44.9 & 51.0 & 52.0 & 54.2 & 49.1 & 44.8 & 48.0 & 42.8 & 49.2 & 48.7 & 48.6 & 51.4 & 46.5 & 56.1 & 49.4 & 48.3 & 0.5 & 48.9 & 3 \\
\hline $\mathrm{Ni}$ & 165 & 180 & 160 & 130 & 180 & 130 & 140 & 110 & 110 & 130 & 160 & 150 & 120 & 130 & 120 & 160 & 25 & 140 & 24 \\
\hline $\mathrm{Br}^{\mathrm{b}}$ & 0.21 & 0.26 & 0.33 & 0.37 & 0.27 & & 0.09 & & & 0.15 & 0.16 & 0.19 & 0.36 & 0.69 & 0.15 & 0.65 & 0.12 & 0.23 & 0.10 \\
\hline Cs & 0.08 & 0.09 & 0.15 & 0.20 & 0.10 & 0.18 & 0.12 & 0.35 & 0.08 & 0.10 & 0.24 & 0.33 & 0.17 & 0.06 & 0.10 & 0.17 & 0.04 & 0.17 & 0.09 \\
\hline $\mathrm{La}$ & 12.5 & 2.61 & 2.65 & 2.65 & 2.65 & 2.49 & 2.59 & 2.54 & 2.64 & 2.62 & 2.60 & 2.60 & 2.71 & 3.13 & 2.58 & 2.69 & 0.05 & 2.61 & 0.06 \\
\hline $\mathrm{Ce}$ & 26.9 & 8.2 & 8.3 & 8.1 & 8.5 & 7.8 & 8.4 & 8.1 & 8.1 & 8.3 & 8.5 & 8.4 & 8.7 & 10.0 & 8.1 & 8.6 & 0.3 & 8.3 & 0.2 \\
\hline $\mathrm{Sm}$ & 3.71 & 3.18 & 3.24 & 3.16 & 3.20 & 3.04 & 3.08 & 3.05 & 3.22 & 3.20 & 3.14 & 3.10 & 3.25 & 3.73 & 3.15 & 3.22 & 0.06 & 3.15 & 0.07 \\
\hline $\mathrm{Eu}$ & 1.21 & 1.10 & 1.10 & 1.13 & 1.12 & 1.09 & 1.06 & 1.10 & 1.14 & 1.16 & 1.15 & 1.11 & 1.14 & 1.33 & 1.14 & 1.16 & 0.03 & 1.12 & 0.03 \\
\hline $\mathrm{Tb}$ & 0.78 & 0.91 & 0.91 & 0.89 & 0.93 & 0.87 & 0.84 & 0.86 & 0.88 & 0.91 & 0.85 & 0.86 & 0.91 & 1.00 & 0.83 & 0.89 & 0.03 & 0.88 & 0.03 \\
\hline $\mathrm{Yb}$ & 2.54 & 3.52 & 3.65 & 3.52 & 3.50 & 3.38 & 3.46 & 3.45 & 3.79 & 3.73 & 3.70 & 3.64 & 3.73 & 4.41 & 3.72 & 3.78 & 0.07 & 3.60 & 0.13 \\
\hline Lu & 0.425 & 0.589 & 0.576 & 0.561 & 0.572 & 0.548 & 0.566 & 0.557 & 0.572 & 0.570 & 0.573 & 0.561 & 0.595 & 0.696 & 0.576 & 0.575 & 0.014 & 0.570 & 0.013 \\
\hline $\mathrm{Hf}$ & 2.47 & 2.30 & 2.24 & 2.30 & 2.23 & 2.25 & 2.18 & 2.22 & 2.45 & 2.41 & 2.36 & 2.38 & 2.43 & 2.58 & 2.36 & 2.42 & 0.08 & 2.32 & 0.09 \\
\hline $\mathrm{Ta}$ & 1.43 & 0.20 & 0.21 & 0.24 & 0.18 & 0.16 & 0.18 & 0.09 & 0.22 & 0.20 & 0.21 & 0.17 & 0.20 & 0.20 & 0.10 & 0.17 & 0.03 & 0.18 & 0.04 \\
\hline Th & 1.58 & 0.08 & 0.15 & 0.25 & 0.17 & 0.21 & 0.11 & 0.19 & 0.11 & 0.16 & 0.16 & 0.13 & 0.14 & 0.12 & 0.17 & 0.15 & 0.04 & 0.16 & 0.04 \\
\hline $\begin{array}{l}\text { Chemical } \\
\text { group }\end{array}$ & I & II & II & II & II & II & II & II & II & II & II & II & II & II & II & II & II & II & II \\
\hline
\end{tabular}

Note: Instrumental neutron activation analysis (INAA) was the method of analysis. $\sigma=$ one standard deviation uncertainty estimate of a single analysis based principally on counting statistics, $\overline{\mathrm{x}}=$ mean, ans $\mathrm{s}=$ sample standard deviation. $\mathrm{FeO}^{*}=$ total $\mathrm{Fe}$ as $\mathrm{FeO} . \mathrm{FeO}^{*}$ and $\mathrm{Na}_{2} \mathrm{O}$ concentrations expressed in wt.\%, all others expressed in ppm.

a These samples contain $>0.6 \mathrm{ppm} \mathrm{Br}$, which indicates interaction with seawater. They were not used to calculate the mean.

b This is an estimated value, no standard was used. 


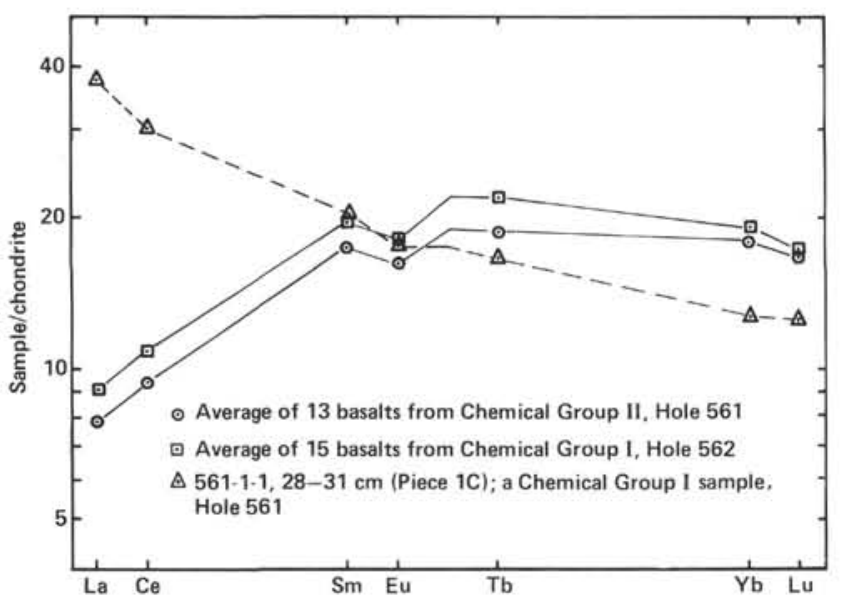

Figure 1. Rare earth element abundance patterns normalized to chondrites for basalts from Holes 561 and 562 .

gous to those found in an Icelandic tholeiitic basalt by Lindstrom and Haskin (1981). Similarly, the discrepancies between analytical uncertainty and sample standard deviation for $\mathrm{FeO}^{*}$ and $\mathrm{Co}$ in the 15 basalts from Chemical Group II are on the same order of magnitude as small-scale heterogeneity between separate hand-specimens of this mass range $(2.9-11.8 \mathrm{~g})(100[\mathrm{~s} / \overline{\mathrm{x}}]=$ relative heterogeneity; $3.8 \%$ for $\mathrm{FeO}^{*}$ and $6.1 \%$ for $\mathrm{Co}$ ).

The composition of basalts from Chemical Group II is homogeneous for all elements listed in Table 2 to within $2 \sigma$ analytical uncertainty except for $\mathrm{FeO}^{*}$, Co, and Cs. Any quantitative petrogenetic model used to describe the relationship of basalts from Chemical Group II to other basalts or its mantle source is limited by the analytical uncertainty for those elements found to be homogeneous and by the relative heterogeneity of $\mathrm{FeO}^{*}, \mathrm{Co}$, and Cs.

\section{CHEMICAL GROUP I, HOLE 562}

Basalts from Hole 562 are sparsely to moderately plagioclase phyric. Most were extruded as pillows up to 1.5 $\mathrm{m}$ thick, but two thicker flows $(3.7$ and $5.1 \mathrm{~m})$ occur. These are minimum thicknesses because recovery was only 62 and $77 \%$ for Cores $562-4$ and 562-5, where these occur. The basalts are fresh to moderately altered with the alteration occurring primarily adjacent to fractures, veins, or glassy margins. Although no lithologic changes are apparent, two distinct chemical groups were proposed on the basis of shipboard XRF analyses. Chemical Group $\mathrm{I}$ is higher in $\mathrm{TiO}_{2}, \mathrm{Fe}_{2} \mathrm{O}_{3}$ (total iron as $\left.\mathrm{Fe}_{2} \mathrm{O}_{3}\right), \mathrm{P}_{2} \mathrm{O}_{5}, \mathrm{~V}, \mathrm{Y}$, and $\mathrm{Zr}$ are lower in $\mathrm{Al}_{2} \mathrm{O}_{3}$ and $\mathrm{CaO}$, relative to Chemical Group II.

Analyses of 16 basalts from Chemical Group I are tabulated in Table 3. The LREE-depleted nature relative to chondrites of these basalts is illustrated in Figure 1. Samples collected from Sections 562-4-1 through 562-4-3 are part of the $3.7-\mathrm{m}$ thick flow and those from Sections 562-5-2 through 562-5-5 are part of the 5.1-m thick flow. Sample 562-4-3, 86-88 cm (Piece 2H) (collected $5 \mathrm{~cm}$ above the basal chilled glass rim) was not included in the mean or standard deviation because its Cs concen- tration $(0.85 \mathrm{ppm})$ is higher-by at least a factor of $3-$ than any other analyzed sample from this group, which indicates a greater uptake of Cs from seawater (Bougault et al., 1979). The mean and standard deviation for each thick flow were calculated, but they are not tabulated here because they are essentially identical (to within analytical uncertainty) to the mean and standard deviation of all 15 samples. For only $\mathrm{FeO}^{*}, \mathrm{Na}_{2} \mathrm{O}, \mathrm{Sc}$, and $\mathrm{Co}$, does s exceed $\sigma$ by more than a factor of 2 . The scatter in the $\mathrm{Na}_{2} \mathrm{O}$ data could be attributed to the increase of alkali metals with increased alteration (Bougault et al., 1979). The scatter in $\mathrm{FeO}^{*}, \mathrm{Sc}$, and $\mathrm{Co}$ is on the same order of magnitude as small-scale heterogeneity from one hand-specimen to the next for this mass range (6.2$25.0 \mathrm{~g})(100[\mathrm{~s} / \overline{\mathrm{x}}]=$ relative heterogeneity; $2.8 \%$ for $\mathrm{FeO}^{*}, 3.0 \%$ for $\mathrm{Sc}$, and $2.1 \%$ for $\mathrm{Co}$ ).

The composition of basalts from Chemical Group I is homogeneous for all elements listed in Table 3 to within $2 \sigma$ analytical uncertainty except for $\mathrm{FeO}^{*}, \mathrm{Na}_{2} \mathrm{O}, \mathrm{Sc}$, and $\mathrm{Co}$. Comparing those elements $\left(\mathrm{FeO}^{*}\right.$ and $\left.\mathrm{Co}\right)$ that are heterogeneous beyond analytical uncertainty in both Chemical Group II (Hole 561) and Chemical Group I (Hole 562), the basalts from Hole 561 are slightly more heterogeneous in those elements than the basalts from Hole 562 (3.8\% relative heterogeneity as opposed to $2.8 \%$ for $\mathrm{FeO}^{*}$ and $6.1 \%$ relative heterogeneity as opposed to $2.1 \%$ for $\mathrm{Co}$ ).

\section{HOLE 564}

At Site 564, $35 \mathrm{~m}$ of basalts were recovered from an 81-m cored section of the basement. Five lithologic units from the basement-sediment interface to the bottom of the core were proposed aboard ship (Unit 3, aphyric pillow basalts; Unit 4, a 4-m thick (minimum thickness) aphyric basalt flow; Unit 5, aphyric pillow basalts; Unit 6, a 2.5-m thick olivine microphyric basalt; and Unit 7, aphyric pillow basalts).

Even though a chemical gradient was apparent in the XRF shipboard analyses as a function of depth (Fig. 2), the basalts from Hole 564 were defined as a single chemical group and much of the chemical variation was attributed to analytical precision. It was noted, however, that this apparent chemical gradient with depth should be investigated onshore.

Analyses for 19 basalts from Hole 564 are listed in Table 4. Samples from 564-2-1 through 564-5-2 correspond to Lithologic Unit 3. Four samples were collected from a single pillow (A) within this lithologic unit (samples from 564-2-1 through 564-2-2). Six samples from 564-6-3 through 564-6-5 were collected from Lithologic Unit 4 (Flow B), a 4-m thick flow. Samples from Sections 564-8-1 through 564-8-2 correspond to Lithologic Unit 5. Four samples from 564-8-1 were collected from a single pillow (C) in this pillow sequence. Sample 564-9-2, $142-144 \mathrm{~cm}$ (Piece 9C) is the only sample from Lithologic Unit 7. An increase in the concentrations of REE, $\mathrm{Ta}$, and $\mathrm{Th}$ and a decrease in $\mathrm{Cr}$ are readily apparent as Table 4 is read from left to right (top to bottom of the core). This same type of trend of increasing incompatible trace element concentrations and decreasing $\mathrm{Cr}$ con- 
Table 3. Elemental abundances of basalts from Chemical Group I, Hole 562.

\begin{tabular}{|c|c|c|c|c|c|c|c|c|c|c|c|c|c|c|c|c|c|c|c|}
\hline $\begin{array}{l}\text { Core-Section } \\
\text { Interval (in cm) } \\
\text { Piece }\end{array}$ & $\begin{array}{c}3-1 \\
46-48 \\
\text { ID }\end{array}$ & $\begin{array}{c}4-1 \\
14-16 \\
\text { IB }\end{array}$ & $\begin{array}{c}4-1 \\
58-60 \\
3 \mathrm{~A}\end{array}$ & $\begin{array}{c}4-1 \\
78-80 \\
3 \mathrm{~B}\end{array}$ & $\begin{array}{c}4-2 \\
22-25 \\
1 \mathrm{~A}\end{array}$ & $\begin{array}{c}4-3 \\
27-29 \\
2 B\end{array}$ & $\begin{array}{c}4-3 \\
64-67 \\
2 \mathrm{~F}\end{array}$ & $\begin{array}{c}4-3^{\mathrm{a}} \\
86-88 \\
2 \mathrm{H}\end{array}$ & $\begin{array}{c}4-4 \\
117-119 \\
8 \mathrm{~B}\end{array}$ & $\begin{array}{c}4-5 \\
26-28 \\
2 A\end{array}$ & $\begin{array}{c}5-2 \\
89-91 \\
4 \mathrm{~B}\end{array}$ & $\begin{array}{c}5-3 \\
9-11 \\
1 \mathrm{~A}\end{array}$ & $\begin{array}{c}5-3 \\
58-60 \\
1 \mathrm{E}\end{array}$ & $\begin{array}{c}5-4 \\
106-108 \\
2 A\end{array}$ & $\begin{array}{c}5-5 \\
69-71 \\
3 \mathrm{C}\end{array}$ & $\begin{array}{c}5-5 \\
95-97 \\
4 \mathrm{~A}\end{array}$ & $\sigma$ & $\overline{\mathrm{x}}$ & $\mathrm{s}$ \\
\hline $\mathrm{FeO}^{*}$ & 10.10 & 10.89 & 10.54 & 10.19 & 10.22 & 10.25 & 10.69 & 10.88 & 9.70 & 10.02 & 10.60 & 10.34 & 10.22 & 10.05 & 10.28 & 10.33 & 0.11 & 10.29 & 0.29 \\
\hline $\mathrm{Na}_{2} \mathrm{O}$ & 2.51 & 2.71 & 2.52 & 2.62 & 2.51 & 2.48 & 2.54 & 2.69 & 2.34 & 2.50 & 2.47 & 2.56 & 2.47 & 2.64 & 2.50 & 2.52 & 0.03 & 2.53 & 0.08 \\
\hline $\mathrm{Sc}^{2}$ & 40.8 & 42.0 & 41.6 & 42.3 & 39.8 & 39.1 & 40.2 & 42.1 & 37.7 & 40.1 & 40.3 & 40.5 & 39.2 & 40.1 & 40.2 & 39.2 & 0.4 & 40.2 & 1.2 \\
\hline $\mathrm{Cr}$ & 235 & 240 & 239 & 245 & 234 & 231 & 237 & 239 & 226 & 241 & 243 & 240 & 234 & 238 & 238 & 237 & 3 & 237 & 4.8 \\
\hline Co & 42.1 & 42.8 & 42.1 & 43.5 & 41.5 & 41.6 & 41.6 & 38.8 & 39.7 & 42.2 & 42.4 & 42.7 & 41.0 & 41.8 & 42.1 & 41.3 & 0.4 & 41.9 & 0.9 \\
\hline $\begin{array}{l}\mathrm{Ni} \\
\mathrm{Br}^{\mathrm{b}}\end{array}$ & 120 & 30 & $\begin{array}{l}100 \\
0.08\end{array}$ & 110 & 120 & 150 & 110 & 100 & 110 & 100 & 100 & 110 & $\begin{array}{l}100 \\
0.14\end{array}$ & 70 & 70 & 90 & 27 & 100 & 27 \\
\hline Cs & 0.05 & 0.27 & 0.03 & 0.04 & 0.03 & 0.02 & 0.30 & 0.85 & 0.01 & 0.06 & 0.04 & 0.05 & 0.04 & 0.07 & 0.01 & 0.20 & 0.05 & 0.08 & 0.10 \\
\hline $\mathrm{La}$ & 2.70 & 3.03 & 3.07 & 2.94 & 2.90 & 2.85 & 2.91 & 3.08 & 2.94 & 3.06 & 3.14 & 3.17 & 2.99 & 3.12 & 3.10 & 3.01 & 0.06 & 3.00 & 0.12 \\
\hline $\mathrm{Ce}$ & 9.0 & 9.8 & 9.4 & 9.6 & 9.0 & 9.0 & 9.4 & 9.6 & 9.2 & 9.8 & 9.9 & 10.0 & 9.4 & 9.8 & 9.6 & 9.0 & 0.3 & 9.5 & 0.4 \\
\hline $\mathrm{Sm}$ & 3.49 & 3.69 & 3.68 & 3.59 & 3.51 & 3.46 & 3.45 & 3.73 & 3.43 & 3.68 & 3.64 & 3.71 & 3.56 & 3.65 & 3.66 & 3.57 & 0.06 & 3.58 & 0.10 \\
\hline Eu & 1.22 & 1.29 & 1.29 & 1.27 & 1.22 & 1.20 & 1.26 & 1.30 & 1.19 & 1.24 & 1.27 & 1.25 & 1.22 & 1.23 & 1.22 & 1.19 & 0.03 & 1.24 & 0.03 \\
\hline $\mathrm{Tb}$ & 1.02 & 1.06 & 1.07 & 1.06 & 1.03 & 1.02 & 1.05 & 1.12 & 1.00 & 1.04 & 1.06 & 1.05 & 1.01 & 1.03 & 1.04 & 1.04 & 0.06 & 1.04 & 0.02 \\
\hline $\mathrm{Yb}$ & 3.72 & 3.86 & 3.88 & 3.88 & 3.64 & 3.62 & 3.69 & 3.91 & 3.61 & 3.88 & 3.80 & 3.93 & 3.74 & 3.91 & 3.97 & 3.79 & 0.11 & 3.79 & 0.12 \\
\hline Lu & 0.570 & 0.59 & 0.598 & 0.58 & 0.566 & 0.542 & 0.55 & 0.60 & 0.56 & 0.59 & 0.59 & 0.60 & 0.59 & 0.59 & 0.61 & 0.58 & 0.02 & 0.582 & 0.019 \\
\hline $\mathrm{Hf}$ & 2.73 & 2.74 & 2.75 & 2.73 & $2.54^{\circ}$ & 2.57 & 2.63 & 2.81 & 2.56 & 2.68 & 2.74 & 2.69 & 2.58 & 2.60 & 2.66 & 2.57 & 0.12 & 2.65 & 0.08 \\
\hline $\mathrm{Ta}$ & 0.16 & 0.18 & 0.20 & 0.19 & 0.19 & 0.21 & 0.19 & 0.18 & 0.19 & 0.19 & 0.23 & 0.21 & 0.22 & 0.22 & 0.19 & 0.22 & 0.03 & 0.20 & 0.02 \\
\hline Th & 0.12 & 0.29 & 0.05 & 0.10 & 0.20 & 0.03 & 0.09 & 0.08 & 0.14 & 0.10 & 0.21 & 0.21 & 0.10 & 0.17 & 0.07 & 0.10 & 0.04 & 0.13 & 0.07 \\
\hline
\end{tabular}

Note: Instrumental neutron activation analysis (INAA) was the method of analysis. $\sigma=$ one standard deviation uncertainty estimate of a single analysis based principally on counting statistics, $\overline{\mathrm{x}}=$ mean, and $\mathrm{s}=$ sample standard deviation. $\mathrm{FeO}^{\circ}=$ total $\mathrm{Fe}$ as $\mathrm{FeO}$. $\mathrm{FeO}$ and $\mathrm{Na}_{2} \mathrm{O}$ concentrations expressed in wt.\%, all others expressed in ppm.

a This sample contains at least three times as much Cs than all the other samples, which indicates alteration. It was not used to calculate the mean.

$\mathrm{b}$ This is an estimated value, no standard was used.

Table 4. Elemental abundances of basalts from Hole 564

\begin{tabular}{|c|c|c|c|c|c|c|c|c|c|c|c|c|c|c|c|c|c|c|c|c|}
\hline \multirow{4}{*}{$\begin{array}{l}\text { Core-Section } \\
\text { Interval (in cm) } \\
\text { Piece }\end{array}$} & \multicolumn{4}{|c|}{ Pillow A } & \multirow{3}{*}{$\begin{array}{c}3-2 \\
127-129\end{array}$} & \multirow{3}{*}{$\begin{array}{c}4-2 \\
40-54\end{array}$} & \multirow{3}{*}{$5-2$} & \multicolumn{6}{|c|}{ Flow B } & \multicolumn{4}{|c|}{ Pillow C } & \multirow{3}{*}{$\begin{array}{c}8-2 \\
22-25\end{array}$} & \multirow[b]{2}{*}{$9-2$} & \multirow[b]{4}{*}{$\sigma$} \\
\hline & $2-1$ & $2-2$ & $2-2$ & $2-2$ & & & & $6-3$ & $6-4$ & $6-4$ & $6-4$ & $6-5$ & $6-5$ & $8-1$ & $8-1$ & $8-1$ & $8-1$ & & & \\
\hline & $145-150$ & $1-4$ & $15-22$ & $65-67$ & & & & $141-143$ & $15-17$ & $38-40$ & $139-142$ & $22-24$ & $58-61$ & $10-14$ & $25-27$ & $44-47$ & $76-79$ & & $142-144$ & \\
\hline & $10 \mathrm{C}$ & 1 & $2 \mathrm{~A}$ & $4 \mathrm{~B}$ & $7 \mathrm{~A}$ & 3D & $2 \mathrm{D}$ & 10 & $2 \mathrm{~A}$ & $2 \mathrm{D}$ & $2 \mathrm{~K}$ & $1 \mathrm{E}$ & $2 \mathrm{C}$ & $2 \mathrm{~A}$ & $2 \mathrm{C}$ & $2 \mathrm{E}$ & 3 & 2 & 9 & \\
\hline $\mathrm{FeO}^{*}$ & 10.73 & 10.73 & 10.67 & 10.82 & 10.46 & 10.66 & 10.26 & 10.98 & 10.33 & 10.41 & 10.75 & 10.44 & 10.77 & 11.30 & 10.88 & 11.46 & 11.74 & 11.14 & 10.84 & 0.11 \\
\hline $\mathrm{Na}_{2} \mathrm{O}$ & 2.33 & 2.38 & 2.36 & 2.42 & 2.30 & 2.30 & 2.31 & 2.34 & 2.36 & 2.32 & 2.41 & 2.31 & 2.34 & 2.51 & 2.40 & 2.48 & 2.54 & 2.42 & 2.38 & 0.03 \\
\hline $\mathrm{Sc}$ & 42.4 & 42.8 & 42.1 & 42.2 & 42.0 & 41.6 & 42.0 & 42.6 & 41.6 & 41.8 & 42.6 & 42.2 & 41.5 & 43.0 & 42.7 & 43.2 & 44.6 & 42.6 & 42.5 & 0.4 \\
\hline $\mathrm{Cr}$ & 259 & 267 & 262 & 245 & 255 & 248 & 247 & 244 & 240 & 235 & 242 & 239 & 235 & 220 & 239 & 240 & 243 & 239 & 238 & 3 \\
\hline co & 43.1 & 41.0 & 43.7 & 34.8 & 46.6 & 43.4 & 48.0 & 43.5 & 43.8 & 44.5 & 44.8 & 45.1 & 44.3 & 45.2 & 44.5 & 43.5 & 31.5 & 40.1 & 52.2 & 0.4 \\
\hline $\mathrm{Ni}$ & 70 & 110 & 120 & 110 & 130 & 120 & 160 & 70 & 130 & 115 & 130 & 120 & 120 & 140 & 110 & 130 & 70 & 100 & 90 & 28 \\
\hline$B r^{a}$ & 0.16 & & 0.12 & 0.6 & & & & & & & & & & 0.6 & & & 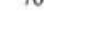 & & & \\
\hline Cs & 0.14 & 0.36 & 0.30 & 0.12 & 0.46 & 0.35 & 0.37 & 0.27 & 0.31 & 0.31 & 0.05 & 0.08 & 0.44 & 0.16 & 0.43 & 0.37 & 0.08 & 0.37 & 0.33 & 0.06 \\
\hline $\mathrm{La}$ & 3.38 & 3.45 & 3.34 & 3.51 & 3.49 & 3.48 & 3.75 & 3.89 & 3.93 & 3.89 & 3.84 & 3.95 & 4.00 & 4.42 & 4.11 & 4.26 & 4.49 & 4.19 & 4.24 & 0.06 \\
\hline $\mathrm{Ce}$ & 10.1 & 10.0 & 10.1 & 10.5 & 10.6 & 10.5 & 10.8 & 11.2 & 11.1 & 11.1 & 11.1 & 11.0 & 11.2 & 11.5 & 11.9 & 12.1 & 12.5 & 11.7 & 11.7 & 0.3 \\
\hline Sm & 3.35 & 3.39 & 3.31 & 3.33 & 3.33 & 3.30 & 3.41 & 3.47 & 3.46 & 3.45 & 3.44 & 3.49 & 3.45 & 3.58 & 3.54 & 3.65 & 3.82 & 3.59 & 3.47 & 0.05 \\
\hline $\mathrm{Eu}$ & 1.15 & 1.20 & 1.18 & 1.19 & 1.19 & 1.19 & 1.20 & 1.22 & 1.20 & 1.21 & 1.21 & 1.21 & 1.20 & 1.27 & 1.25 & 1.29 & 1.32 & 1.23 & 1.22 & 0.03 \\
\hline $\mathrm{Tb}$ & 0.93 & 0.90 & 0.94 & 0.93 & 0.90 & 0.97 & 0.97 & 0.99 & 0.95 & 0.96 & 0.98 & 0.99 & 0.99 & 1.06 & 1.03 & 1.03 & 1.05 & 0.99 & 1.00 & 0.06 \\
\hline $\mathrm{Yb}$ & 3.58 & 3.63 & 3.59 & 3.58 & 3.64 & 3.60 & 3.72 & 3.72 & 3.64 & 3.67 & 3.63 & 3.60 & 3.57 & 3.79 & 3.75 & 3.76 & 3.93 & 3.71 & 3.62 & 0.09 \\
\hline Lu & 0.57 & 0.58 & 0.57 & 0.57 & 0.56 & 0.56 & 0.58 & 0.58 & 0.58 & 0.58 & 0.575 & 0.579 & 0.575 & 0.593 & 0.578 & 0.603 & 0.640 & 0.581 & 0.567 & 0.018 \\
\hline $\mathrm{Hf}$ & 2.45 & 2.69 & 2.48 & 2.46 & 2.58 & 2.56 & 2.73 & 2. & 2.67 & 2.65 & 2.84 & 2.78 & 2.73 & 2.83 & 2.81 & 2.87 & 2.91 & 2.80 & 2.67 & 0.11 \\
\hline $\mathrm{Ta}$ & 0.22 & 0.28 & 0.28 & 0.37 & 0.33 & 0.32 & 0.34 & 0.37 & 0.37 & 0.38 & 0.36 & 0.32 & 0.33 & 0.37 & 0.39 & 0.36 & 0.38 & 0.35 & 0.35 & 0.03 \\
\hline $\mathrm{Th}$ & 0.20 & 0.22 & 0.19 & 0.20 & 0.20 & 0.22 & 0.25 & 0.23 & 0.25 & 0.26 & 0.26 & 0.30 & 0.26 & 0.34 & 0.33 & 0.31 & 0.32 & 0.31 & 0.32 & 0.05 \\
\hline Zone & 1 & 1 & 1 & $\mathrm{v}$ & 1 & 1 & 1 & 1 & 1 & 1 & 1 & 1 & 1 & $\mathrm{v}$ & 1 & 1 & 1 & 1 & $\mathrm{v}$ & \\
\hline
\end{tabular}

Note: Instrumental neutron activation analysis (INAA) was the method of analysis. I = interior portion of pillow, $\mathrm{V}=$ variolitic portion of pillow or flow. $\sigma=$ one standard deviation uncertainty estimate of a single analysis based principally on counting statistics. $\mathrm{FeO}^{*}=$ total $\mathrm{Fe}$ as $\mathrm{FeO} . \mathrm{FeO}^{*}$ and $\mathrm{Na}_{2} \mathrm{O}$ concentrations in wt.\%, all others in ppm. 


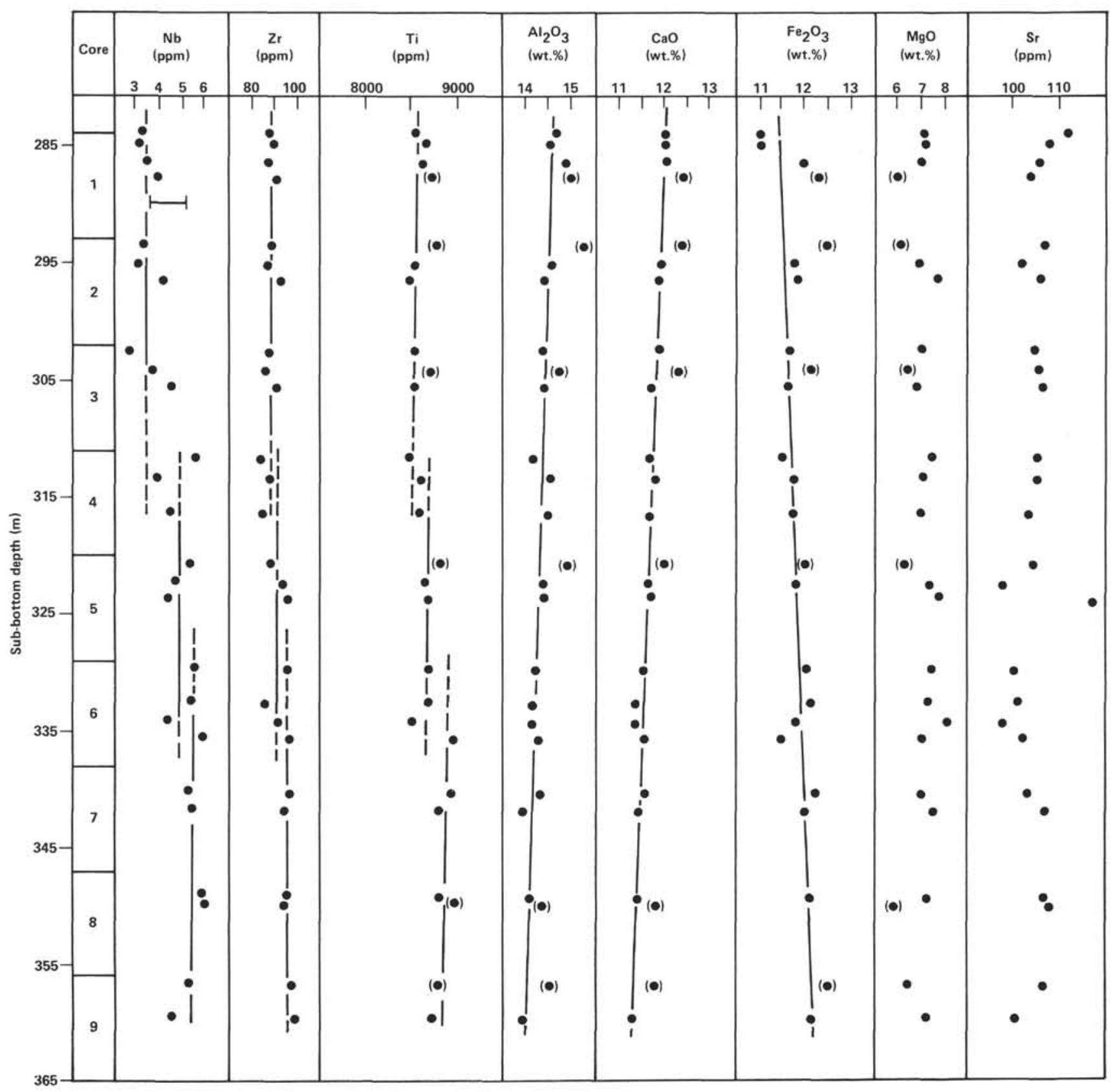

Figure 2. Downhole variations in chemical abundance of basalts from Hole 564, oxide concentrations are weight percent (wt.\%), element concentrations are parts per million (ppm).

centrations with depth in the hole was observed in a sequence of sheet flows and submarine pahoehoe units at Site 462 of Leg 61 by Batiza (1981).

The mean and sample standard deviation for three recognizable structures from Hole 564 (Pillow A, Flow B, and Pillow C) are listed in Table 5. Samples from variolitic zones from Pillows $\mathrm{A}$ and $\mathrm{C}$ that appear altered (brown coloration rather than the gray color of the unaltered basalt) are not included in the mean or standard deviation calculation. They will be discussed later in detail. Only the sample standard deviation for Co exceeds its analytical uncertainty by a factor of 2 in Pillow A. The standard deviations of $\mathrm{FeO}^{*}$ and $\mathrm{Cs}$ exceed their an- alytical uncertainties by a factor of 2 in Flow B. The standard deviations of $\mathrm{FeO}^{*}, \mathrm{Na}_{2} \mathrm{O}, \mathrm{Sc}, \mathrm{Co}, \mathrm{Cs}, \mathrm{La}$, and $\mathrm{Sm}$ exceed their analytical uncertainties by a factor of 2 in Pillow C.

Analyses of multiple samples from separate structures in this core gives us an idea of the intrastructure chemical variations. Pillow A is homogeneous to within $2 \sigma$ analytical uncertainty for all elements listed in Table 5 except Co. This can be attributed to small-scale heterogeneity within the pillow with a relative heterogeneity of $3.3 \%$. Flow B is homogeneous to within $2 \sigma$ analytical uncertainty except for $\mathrm{FeO}^{*}$ and Cs. Variations in Cs concentrations are again more easily explained by uptake of 
Table 5. Average elemental abundances and standard deviation for Pillows A and C and Flow B for the basalts from Hole 564 .

\begin{tabular}{|c|c|c|c|c|c|c|c|}
\hline \multirow{3}{*}{$\mathrm{n}$} & \multicolumn{2}{|c|}{ Pillow A } & \multicolumn{2}{|c|}{ Flow B } & \multicolumn{2}{|c|}{ Pillow C } & \multirow[b]{3}{*}{$\sigma$} \\
\hline & \multicolumn{2}{|c|}{3} & \multicolumn{2}{|c|}{6} & \multicolumn{2}{|c|}{3} & \\
\hline & $\overline{\mathrm{x}}$ & $s$ & $\overline{\mathrm{x}}$ & $s$ & $\overline{\mathrm{x}}$ & $s$ & \\
\hline $\mathrm{FeO}^{*}$ & 10.71 & 0.03 & 10.70 & 0.26 & 11.36 & 0.44 & 0.11 \\
\hline $\mathrm{Na}_{2} \mathrm{O}$ & 2.36 & 0.02 & 2.35 & 0.04 & 2.47 & 0.07 & 0.03 \\
\hline $\mathrm{Sc}$ & 42.4 & 0.3 & 42.1 & 0.5 & 43.5 & 1.0 & 0.4 \\
\hline $\mathrm{Cr}$ & 263 & 4 & 239 & 4 & 241 & 2 & 3 \\
\hline Co & 42.6 & 1.4 & 44.3 & 0.6 & 40 & 7 & 0.4 \\
\hline $\mathrm{Ni}$ & 100 & 26 & 114 & 22 & 103 & 31 & 28 \\
\hline Cs & 0.27 & 0.11 & 0.24 & 0.15 & 0.29 & 0.19 & 0.06 \\
\hline La & 3.39 & 0.06 & 3.92 & 0.06 & 4.29 & 0.19 & 0.06 \\
\hline $\mathrm{Ce}$ & 10.07 & 0.06 & 11.12 & 0.08 & 12.2 & 0.3 & 0.3 \\
\hline $\mathrm{Sm}$ & 3.35 & 0.04 & 3.46 & 0.018 & 3.67 & 0.14 & 0.05 \\
\hline Eu & 1.18 & 0.03 & 1.208 & 0.008 & 1.27 & 0.02 & 0.03 \\
\hline $\mathrm{Tb}$ & 0.92 & 0.02 & 0.977 & 0.018 & 1.037 & 0.012 & 0.06 \\
\hline $\mathrm{Yb}$ & 3.60 & 0.03 & 3.64 & 0.05 & 3.81 & 0.10 & 0.09 \\
\hline Lu & 0.573 & 0.006 & 0.578 & 0.002 & 0.591 & 0.013 & 0.018 \\
\hline $\mathrm{Hf}$ & 2.54 & 0.13 & 2.72 & 0.08 & 2.86 & 0.05 & 0.11 \\
\hline $\mathrm{Ta}$ & 0.26 & 0.03 & 0.36 & 0.02 & 0.377 & 0.015 & 0.03 \\
\hline Th & 0.20 & 0.015 & 0.26 & 0.02 & 0.320 & 0.010 & 0.05 \\
\hline
\end{tabular}

Note: $\mathrm{n}=$ number of samples analyzed. $\sigma=$ one standard deviation uncertainty estimate of a single analysis based principally on counting statistics, $\bar{x}=$ mean, and $\mathrm{s}=$ sample standard deviation. $\mathrm{FeO}^{*}=$ total $\mathrm{Fe}$ as $\mathrm{FeO} . \mathrm{FeO}^{*}$ and $\mathrm{Na}_{2} \mathrm{O}$ concentrations expressed in wt. \%, all others expressed in ppm.

Cs from seawater, and small-scale intrastructure sample heterogeneity can account for the variability of $\mathrm{FeO}^{*}$ ( $2.4 \%$ relative heterogeneity).

Pillow $\mathrm{C}$ is homogeneous to within $2 \sigma$ analytical uncertainty except for $\mathrm{FeO}^{*}, \mathrm{Na}_{2} \mathrm{O}, \mathrm{Sc}, \mathrm{Co}, \mathrm{Cs}, \mathrm{La}$, and $\mathrm{Sm}$. The section (564-8-1) that contains this pillow is described as moderately to highly altered in the core description of the site chapter for Site 564 (this volume). Even though only the freshest portions of the pillow were sampled, the general degree of alteration is greater than that found in Pillow A and Flow B. This increased alteration may account for much of the scatter in the data for all these elements, certainly it does for $\mathrm{Na}_{2} \mathrm{O}$ and $\mathrm{Cs}$. The scatter found in the data of $\mathrm{FeO}^{*}, \mathrm{Sc}, \mathrm{Co}, \mathrm{La}$, and Sm may be analogous to the short-range segregation model in which the proportions of phenocrysts, groundmass minerals, and residual liquid vary randomly among different samples of an Icelandic tholeiitic flow (Lindstrom and Haskin, 1981). There is some petrographic evidence for this process. These basalts are characterized by varying proportions of domains with contrasting grain size and texture. Coarse-grained domains range from $10-15 \%$ to $60-70 \%$ of the rock. For a more detailed description, see the site chapter, Site 564, this volume. The relative heterogeneities for these elements are $\mathrm{FeO}^{*}=3.9 \%, \mathrm{Sc}=2.3 \%, \mathrm{Co}=17.5 \%, \mathrm{La}=4.4 \%$, and $\mathrm{Sm}=3.8 \%$.

The intrastructure chemical variations have been established for the two pillows and the 4-m thick flow. Pillow A and Flow B are quite homogeneous and Pillow C is less so.

Are these three structures, which are each in a different lithologic unit, chemically alike or different? A t-test can be used to answer this question (Till, 1974). The ratios of the means of the elements for each structure to the other two structures and the composite sample standard deviations illustrate the results of the t-test graphi- cally (Fig. 3). The means of Pillow A and Flow B are statistically different for $\mathrm{Cr}, \mathrm{La}, \mathrm{Ce}, \mathrm{Sm}, \mathrm{Tb}, \mathrm{Ta}$, and Th. The means of Pillow A and Pillow $\mathrm{C}$ are statistically different for $\mathrm{Cr}, \mathrm{La}, \mathrm{Ce}, \mathrm{Eu}, \mathrm{Tb}, \mathrm{Hf}, \mathrm{Ta}$, and $\mathrm{Th}$. The variance $\left(\mathrm{s}^{2}\right)$ for $\mathrm{FeO}^{*}, \mathrm{Sm}$, and $\mathrm{Yb}$ is statistically different for Pillows $\mathrm{A}$ and $\mathrm{C}$, thus the t-test cannot be used. The positions of their ratio on Figure 3 are comparable to those ratios of means that are found to be statistically different. Although this observation is not a statistical test, by analogy $\mathrm{FeO}^{*}, \mathrm{Sm}$, and $\mathrm{Yb}$ appear to be different in Pillows A and C. The means of Flow B and Pillow $\mathrm{C}$ are statistically different for $\mathrm{FeO}^{*}, \mathrm{Na}_{2} \mathrm{O}, \mathrm{Sc}, \mathrm{Eu}$, $\mathrm{Tb}, \mathrm{Yb}, \mathrm{Hf}$, and Th. The t-test cannot be used to determine the differences of the means for elements $\mathrm{La}, \mathrm{Ce}$, or $\mathrm{Sm}$ for these two structures. Again the means of these elements appear to be different in Flow B and Pillow C. These results do not support the idea that all the basalts from Hole 564 comprise a single chemical group.

There are also other observations that do not support the single chemical group idea. The ratios of the means of Pillows $\mathrm{A}$ and $\mathrm{C}$ and their respective variolitic zones

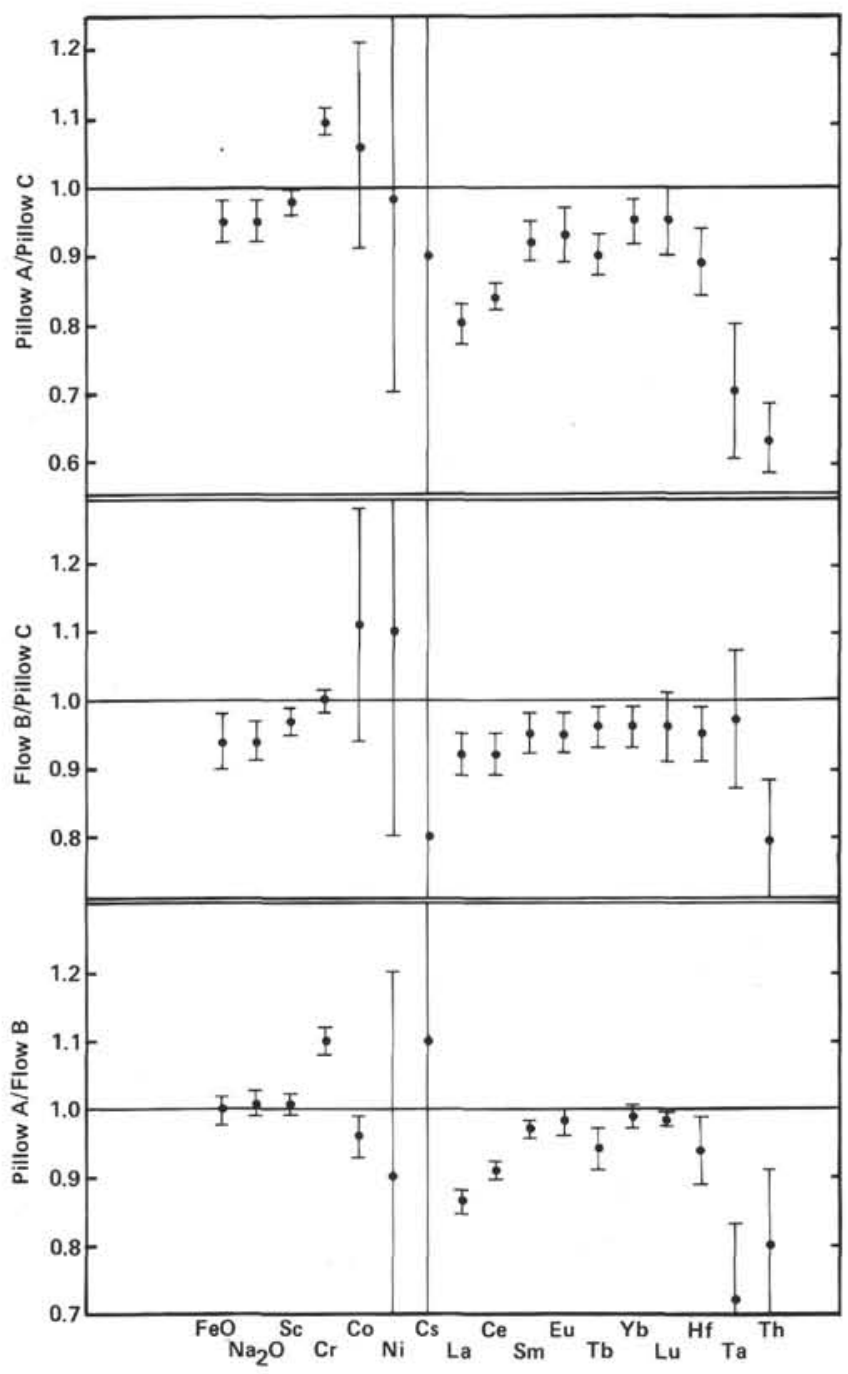

Figure 3. The ratios of average element abundances in three separate structures from Hole 564 . 
are shown in Figure 4. The variolitic zone of Pillow A appears to be depleted in $\mathrm{Co}$ and enriched in $\mathrm{Ta}$ compared to the mean. All other elements in these two portions of the pillow are identical to each other with the composite error of Pillow A sample standard deviation (s) and $\sigma$ for the variolitic zone $\left(\left[s^{2}+\sigma^{2}\right]^{1 / 2}\right)$. The variolitic zone of Pillow $\mathrm{C}$ appears to be depleted only in $\mathrm{Cr}$ compared to the mean. Similar observations have been made. Frey et al. (1974) found that (compared to fresh basalt) altered glass samples are depleted in $\mathrm{Cr}, \mathrm{Ni}$, and V, but Co, Y, Zr, Hf, and Sc show little change. Staudigel et al. (1980) found that (relative to fresh glass), palagonite samples are depleted in $\mathrm{Cr}, \mathrm{Hf}$, and $\mathrm{Sc}$. These variolitic zones that appear to be altered are compositionally closer to their respective pillow interiors than Pillow A, Flow B, and Pillow C are to each other. Also, the relative differences in compositions of basalts defined as distinct chemical groups at a single site (e.g., Site 562, Fig. 5) are less than the differences between these three structures at Site 564 (Fig. 6).

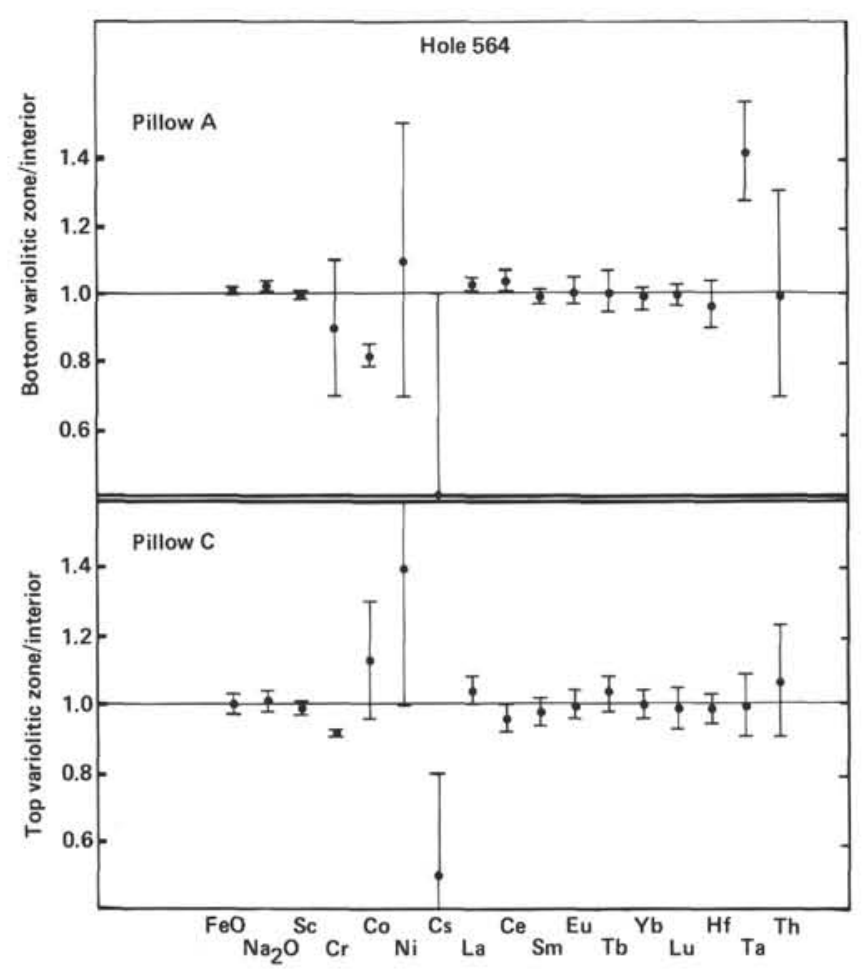

Figure 4. The ratios of element abundances in variolitic zones to the average interior abundances of two pillows.

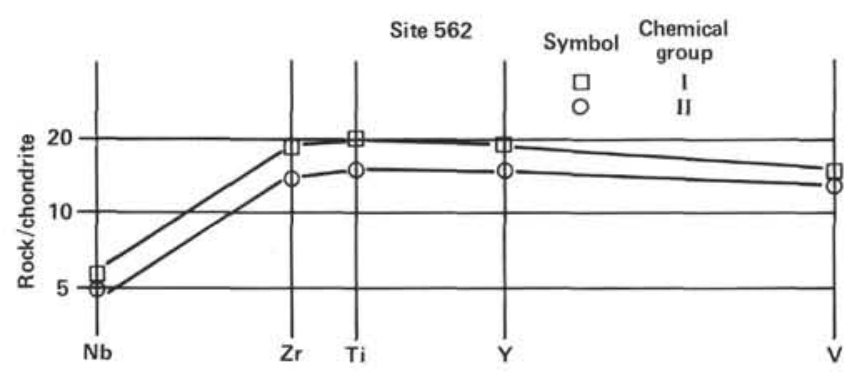

Figure 5. Extended Coryell-Masuda diagram for averages of basalts from Chemical Groups I and II.

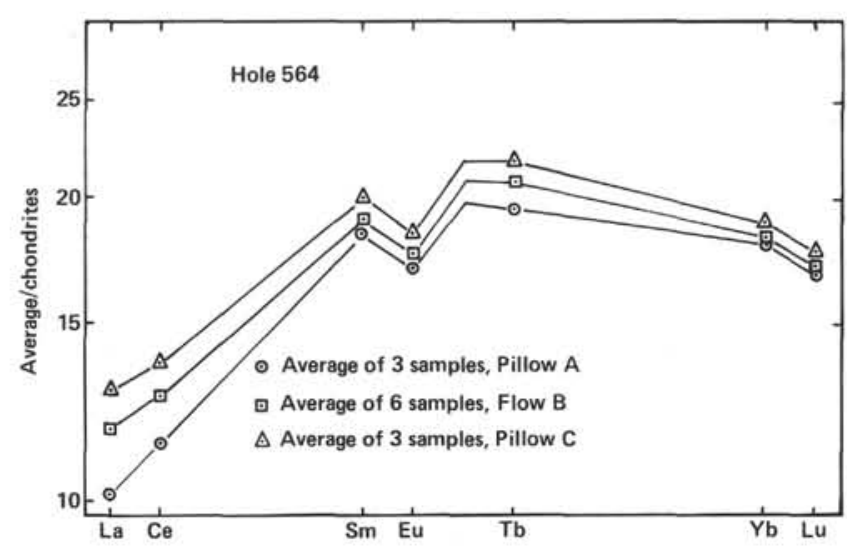

Figure 6. Rare earth element abundances normalized to chondrites for Hole 564 basalts.

\section{SUMMARY}

The composition of basalts from Chemical Group II (Hole 561) are homogeneous to within $2 \sigma$ analytical uncertainty from those elements listed in this paper except for $\mathrm{FeO}^{*}, \mathrm{Co}$, and $\mathrm{Cs}$. The basalts of Chemical Group I (Hole 562) are homogeneous except for $\mathrm{FeO}^{*}, \mathrm{Na}_{2} \mathrm{O}, \mathrm{Sc}$, and $\mathrm{Co}$. Individual pillows and a $4-\mathrm{m}$ thick flow from Hole 564 are homogeneous except for Co in Pillow A, $\mathrm{FeO}^{*}$, and $\mathrm{Cs}$ in Flow $\mathrm{B}$, and $\mathrm{FeO}^{*}, \mathrm{Na}_{2} \mathrm{O}, \mathrm{Sc}, \mathrm{Co}, \mathrm{Cs}$, $\mathrm{La}$, and $\mathrm{Sm}$ in Pillow $\mathrm{C}$.

The scatter in the alkalies is attributed to the addition of these elements during alteration. Often, no other chemical indication of alteration is detectable in otherwise fresh samples. Much of the scatter found in Pillow C may be attributed to alteration, because it is noted to be moderately to highly altered in the core description.

Transition elements $\mathrm{Fe}, \mathrm{Sc}$, and $\mathrm{Co}$ repeatedly have sample standard deviations that exceed $2 \sigma$ analytical uncertainty. This scatter is on the same order of magnitude as the short-range segregation model of Lindstrom and Haskin (1981).

The basalts from Hole 564 were previously defined as a single chemical group even though downhole chemical gradients were found (Site 564 chapter, this vol.). Three individual homogeneous structures that are in separate lithologic units were found to be compositionally distinct to the same degree as the separate chemical groups found in Hole 562. These results do not support the idea that all the basalts from Hole 564 comprise a single chemical group. Obviously, a single sample in this core is only representative of its own structural unit (pillow or flow).

\section{ACKNOWLEDGMENTS}

I thank Randy Korotev, Marilyn and David Lindstrom, and Larry Haskin for constructive readings of the manuscript. Fred A. Frey and John A. Philpotts reviewed the manuscript and suggested changes that improved the final version. This work was supported in part by the National Science Foundation through the DSDP/IPOD grant.

\section{REFERENCES}

Batiza, R., 1981. Trace-element characteristics of Leg 61 basalts. In Larson, R. L., Schlanger, S. O., et al., Init. Repts. DSDP, 61: Washington (U.S. Govt. Printing Office), 689-695.

Bougault, H., Jordan, J., and Treuil, M., 1979. Alteration, fractional crystallization, partial melting, mantle properties from trace ele- 
ments in basalts recovered in North Atlantic. In Talwani, M., Harrison, C. G., and Hays, D. E. (Eds.), Deep Drilling Results in the Atlantic Ocean: Ocean Crust: Washington (Am. Geophys. Union), pp. 352-368.

Deer, W. A., Howie, R. A., and Zussman, J., 1966. An Introduction to the Rock Forming Minerals: London (Logman Group Limited).

Frey, F. A., Bryan, W. B., and Thompson, G., 1974. Atlantic Ocean floor: geochemistry and petrology of basalts from Legs 2 and 3 of the Deep-Sea Drilling Project. J. Geophys. Res., 79:5507-5527.

Hart, S. R., 1969. K, Rb, Cs contents and K/Rb, K/Cs ratios of fresh and altered submarine basalts. Earth Planet. Sci. Lett., 6:295-303. 1976. LIL-element geochemistry, Leg 34 basalts. In Yeats, R. S., Hart, S. R., et al., Init. Repts. DSDP, 34: Washington (U.S. Govt. Printing Office), 283-288.

Haskin, L. A., Haskin, M. A., Frey, F. A., and Wildeman, T. R., 1968. Relative and absolute abundances of the rare earths. In Ahrens, L. H. (Ed.), Origin and Distribution of the Elements: New York (Pergamon Press), pp. 889-912.
Lindstrom, D. J., and Korotev, R. L., 1982. TEABAGS: Computer programs for instrumental neutron activation analysis. J. Radioanal. Chem., 70:439-458.

Lindstrom, M. M., and Haskin, L. A., 1981. Compositional inhomogeneities in a single Icelandic tholeitic flow. Geochim. Cosmochim. Acta, 45:15-31.

Staudigel, H., Frey, F. A., and Hart, S. R., 1980. Incompatible traceelement geochemistry and ${ }^{87 / 86} \mathrm{Sr}$ in basalts and corresponding glasses and palagonites. In Donnelly, T., Francheteau, J., Bryan, W., Robinson, P., Flower, M., Salisbury, M., et al., Init. Repts. $D S D P, 51,52,53$, Pt. 2: Washington (U.S. Govt. Printing Office), $1137-1144$.

Till, R., 1974. Statistical Methods for the Earth Scientist: New York (John Wiley and Sons).

Date of Initial Receipt: 18 April 1983 Date of Acceptance: 5 August 1983 